\title{
Challenges to the clinical application of pluripotent stem cells: towards genomic and functional stability
}

Xuemei $\mathrm{Fu}^{1,2 *}$ and Yang $\mathrm{Xu}^{2 *}$

\begin{abstract}
Human embryonic stem cells (hESCs) can undergo unlimited self-renewal and are pluripotent, retaining the ability to differentiate into all cell types in the body. As a renewable source of various types of human cells, hESCs hold great therapeutic potential. Although significant advances have been achieved in defining the conditions needed to differentiate hESCs into various types of biologically active cells, many challenges remain in the clinical development of hESC-based cell therapy, such as the immune rejection of allogeneic hESC-derived cells by recipients. Breakthroughs in the generation of induced pluripotent stem cells (iPSCs), which are reprogrammed from somatic cells with defined factors, raise the hope that autologous cells derived from patient-specific iPSCs can be transplanted without immune rejection. However, recent genomic studies have revealed epigenetic and genetic abnormalities associated with induced pluripotency, a risk of teratomas, and immunogenicity of some iPSC derivatives. These findings have raised safety concerns for iPSCbased therapy. Here, we review recent advances in understanding the genomic and functional stability of human pluripotent stem cells, current challenges to their clinical application and the progress that has been made to overcome these challenges.

Keywords Embryonic stem cells, induced pluripotent stem cells, cell therapy, immune rejection, genetic stability, epigenetics
\end{abstract}

*Correspondence: xufu@ucsd.edu or yangxu@ucsd.edu

'Chengdu Women's and Children's Central Hospital, Chengdu, Sichuan, China 2Division of Biological Sciences, University of California, San Diego, 9500 Gilman Drive, La Jolla, CA 92093, USA

\section{The clinical importance of human pluripotent stem cells}

As a renewable source of various cell types in the body, human embryonic stem cells (hESCs) hold great promise for cell replacement therapy of many currently untreatable human diseases, including Parkinson's disease, type 1 diabetes (T1D) and heart failure. Since the successful establishment of hESCs in 1998 [1], significant progress has been made in defining the conditions needed to differentiate hESCs into various lineages of biologically active cells. For example, recent studies have shown that cardiomyocytes differentiated from hESCs can rescue heart function after myocardial infarction in animal models $[2,3]$, and the large-scale production of hESCderived cardiomyocytes and their subsequent cryopreservation has recently been achieved [3]. It has also been clinically proven that the transplantation of pancreatic cells harvested from human donors into T1D patients can reverse diabetic phenotypes and restore insulin independence, at least until the graft is eventually rejected [4]. Recent progress in differentiating hESCs into functional pancreatic $\beta$ cells has improved the feasibility of developing hESC-based cell replacement therapy for T1D in the near future [5,6]. Oligodendroglial progenitors differentiated from hESCs have been shown to rescue spinal cord injury in animal models [7], and this approach has been advanced to clinical trial [8]. Following the successful treatment of macular degeneration with hESC-derived retinal pigment epithelium in animal models, a clinical trial has been initiated to treat this disease with hESC-derived retinal pigment epithelium cells [9].

Despite these encouraging advances, several major obstacles remain that hinder the clinical application of these hESC-based cell replacement therapies in patients. One major obstacle is that cells derived from these hESCs have allogeneic antigens (mismatched major human leukocyte antigens (HLAs)), and will therefore be rejected by the immune system of the recipients soon after transplantation. Chronic immune suppression can prevent immune rejection but itself poses serious risks of cancer 
Table 1. Advances in the optimization of tissue culture conditions for clinical development of hESCs

\begin{tabular}{|c|c|c|}
\hline \multicolumn{2}{|c|}{ Optimization of culture conditions of hESCs for clinical use } & \multirow{2}{*}{$\begin{array}{c}\text { References } \\
{[18-21]}\end{array}$} \\
\hline Elimination of xeno-components & Replacement of mouse feeder layer cells with human feeder layer cells & \\
\hline & Replacement of mouse feeder layer cells with human extracellular matrix & {$[22-25]$} \\
\hline & hESC lines successfully banked under good laboratory practice conditions & {$[15-17]$} \\
\hline \multirow[t]{2}{*}{ Scaling up of production of hESCS } & Identification of small molecules that promote hESC self-renewal & [26-29] \\
\hline & Synthetic microcarriers to support hESC culture in suspension & [29-32] \\
\hline
\end{tabular}

and infection [4]. The recent development of induced pluripotent stem cells (iPSCs) has raised the hope that these cells could become a renewable source of autologous cells for transplantation into patients [10]. However, recent studies have identified genomic instability, epigenetic abnormality and immunogenicity of iPSCs and their derivatives, raising safety concerns for their clinical development. In addition, contamination with undifferentiated pluripotent stem cells poses a cancer risk through the potential formation of teratomas in the recipient [11]. Here, we summarize recent progress in understanding the genomic and functional stability of human pluripotent stem cells, current challenges to their clinical application and recent progress in overcoming these challenges.

\section{Clinical applications of human stem cells}

Since the successful transplantation of hematopoietic stem cells (HSCs) from the bone marrow or cord blood for the treatment of various blood-related diseases, stemcell-based therapy has been vigorously pursued to treat various human diseases. Because of their immunomodulatory activity, multi-potency (the ability to differentiate into several cell types) and ability to produce trophic factors that promote tissue regeneration, mesenchymal stem cells are being tested in over 100 clinical trials to determine their efficacy to treat a large panel of human diseases, such as autoimmune diseases, spinal cord injury and myocardial infarction [12]. Some of these clinical trials have shown promising results. In addition, fetalderived neural stem cells have been tested in a clinical trial to treat amyotrophic lateral sclerosis [13]. Although these stem-cell-based therapies are promising, they are limited by the technical difficulty in retrieving these adult- and fetus-derived stem cells, their inability to undergo extensive self-renewal, and the oncogenic potential of the transplanted cells [14]. Human pluripotent stem cells could overcome these hurdles by becoming a renewable source of mesenchymal stem cells and neural stem cells.

The feasibility of the clinical development of hESCbased therapy has been improved by the scalability of hESCs as well as the formulation of chemically defined medium containing material only from human ('xeno-free' medium) for hESC culture (Table 1). Some of the hESC lines have been banked (cryopreserved) under good laboratory practice procedures with minimal involvement of animal components [15-17]. For example, to eliminate the need for mouse feeder layer cells, human feeder layer cells have been established to support the long-term self-renewal of hESCs [18-21]. Recent studies have also shown that the feeder layer can be replaced with purified human extracellular matrix proteins, such as human recombinant laminin-511 and vitronectin, to support the long-term culture of hESCs [22-25]. In addition, the recent development of chemically defined medium with the addition of small molecules that can promote the self-renewal of hESCs greatly facilitates their clinical development [26-29]. The development of synthetic peptide-acrylate surfaces and microcarriers, which can support long-term self-renewal of hESCs in chemically defined and xeno-free medium, further addresses the scalability issue [29-32]. Finally, the successful validation in animal models and initiation of clinical trials of hESC-based therapy described earlier highlights the significant recent advances in their clinical development.

\section{Genome-scale studies of pluripotent stem cells}

Genomic stability of human pluripotent stem cells is a prerequisite for their application in human therapy. The routine method to evaluate the genomic stability of human cells is chromosome karyotyping, which has been used extensively to identify aneuploidy and large chromosomal deletion or duplication. However, this method cannot identify subtle genomic abnormalities, such as missense mutations in coding sequence. Recent advances in genome sequencing have allowed the identification of such subtle genomic aberrations. As a complementary approach, the recent establishment of high-resolution single nucleotide polymorphism (SNP) comparative genome hybridization (CGH) arrays has also enabled the characterization of subtle chromosomal deletions and duplications in pluripotent stem cells. These genomic approaches are becoming increasingly important in the evaluation of the genomic stability of pluripotent stem cells. The recent development of chromatin immunoprecipitation sequencing (ChIP-Seq) and whole-genome bisulfite sequencing has helped to reveal the global 
epigenomic landscape in pluripotent stem cells. These powerful genomic technologies have identified genomic and epigenomic abnormalities of iPSCs. These findings will be discussed in the following sections.

\section{The genomic and functional stability of pluripotent stem cells}

Advances in the genome-scale functional characterization of pluripotent stem cells have revealed challenges for the clinical development of pluripotent stem cells. Here, we discuss recent findings related to the genetic stability, risk of teratoma formation and immunogenicity of hESCs and human iPSCs (hiPSCs).

\section{Genetic stability of pluripotent stem cells Genetic stability of $h E S C s$}

To develop hESCs for cell therapy it is important to scale up their production. Because DNA damage occurs during normal cellular proliferation, the accumulation of unrepaired DNA damage in hESCs during extended proliferation could lead to genetic instability and thus promote tumorigenesis in cells differentiated from hESCs. In support of this notion, high-resolution SNPCGH studies have shown that centrosomal amplification has been associated with extended culture of hESCs [33]. Therefore, it is crucial to elucidate the mechanisms by which ESCs maintain genetic stability. However, the pathways for maintaining the genetic stability of ESCs and somatic cells are not completely conserved [34]. For example, in somatic cells the ataxia-telangiectasia mutated (ATM) protein, a Ser/Thr protein kinase, is the master regulator of cellular responses to DNA double-strand break (DSB) damage and is required for maintaining genomic stability by phosphorylating and activating many DNA repair and cell cycle checkpoint proteins [35]; however, ATM seems not to be as important for maintaining genomic stability in hESCs [36]. Instead, recent studies suggest that the tumor suppressor p53 is important in maintaining hESC genomic stability.

In somatic cells, p53 is a critical transcription factor that directly regulates the expression of hundreds of genes that mediate cell cycle arrest, apoptosis, and senescence [37]. In addition, p53 has transcriptionindependent roles in regulating microRNA (miRNA) processing and metabolism [38,39]. As another example indicating that DNA damage responses in hESCs differ from those in somatic cells, hESCs lack the cell cycle G1/S checkpoint and do not show senescence after DNA damage $[40,41]$. Instead, p53 has a new role in the DNA damage response in ESCs in suppressing the expression of NANOG (a transcription factor required for hESC self-renewal) after DNA damage, leading to the differentiation of DNA-damaged ESCs [41,42]. Therefore, an important mechanism for maintaining

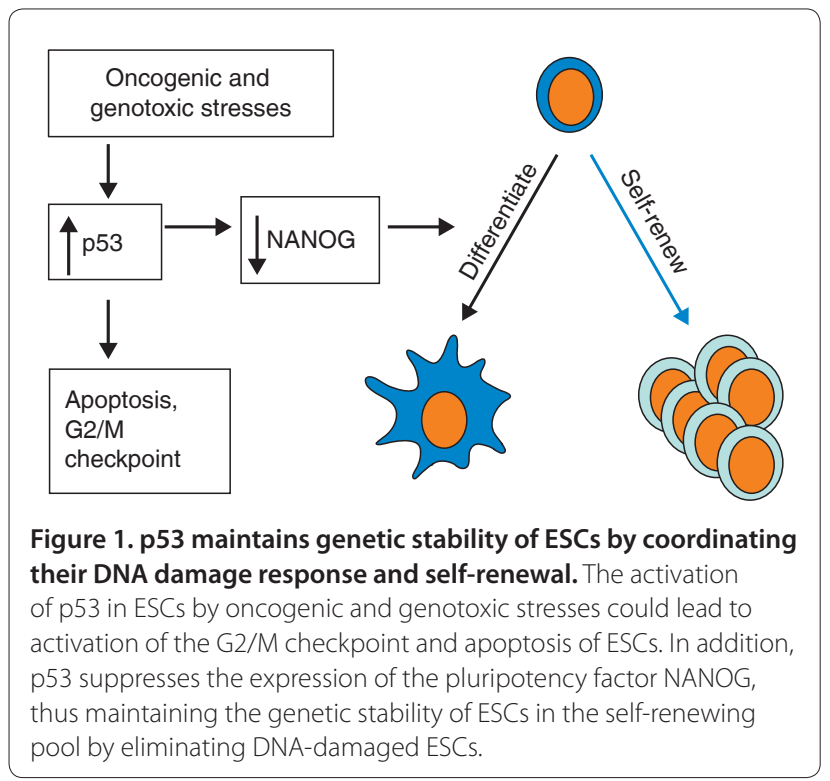

genetic stability in self-renewing ESCs is to eliminate ESCs with DNA damage from the self-renewing pool through differentiation (Figure 1). In addition, p53 is required for the $G_{2} / M$ checkpoint and apoptosis in hESCs after DNA damage [40,41]. In support of the crucial roles of p53 in maintaining genomic stability in hESCs, $\mathrm{p} 53^{-/}$hESCs, generated by sequentially targeting both p53 alleles of hESCs by homologous recombination, show extensive genomic instability during extended proliferation [41]. In summary, although ESCs lack the typical p53-dependent functions, such as cell cycle G1/S checkpoint and senescence, p53 maintains the genomic stability of ESCs by coordinating their DNA damage responses and self-renewal capability (Figure 1). Therefore, it is crucial that the p53 pathway is not adversely affected during long-term expansion of hESCs, for example by the formulation of the tissue culture medium.

\section{Genetic instability of hiPSCs}

The reprogramming factors that have been used to generate iPSCs, including octamer-binding transcription factor 4 (OCT4, also known as POU5F1), sex determining region Y-box 2 (SOX2), NANOG, LIN28, Krüppel-like family of transcription factor 4 (KLF4) and c-MYC, have some oncogenic potential [43]. For example, c-MYC and KLF4 are oncoproteins important for cellular proliferation $[44,45]$. In addition, although NANOG, OCT4 and SOX2 are critical pluripotency factors required for the self-renewal of ESCs, they are also overexpressed in many types of cancers, and their expression has been correlated with poor prognosis of cancer patients [46-49]. LIN28 regulates the expression of miRNA and is highly oncogenic, inducing the expression of oncogenes such 
as c-MYC [50,51]. Therefore, the expression of these reprogramming factors in somatic cells could activate tumor suppressor pathways, including p53 and an alternative reading frame product of the CDKN2A locus (ARF) that is important for activating p53 after oncogenic stress, leading to p53-dependent cell cycle arrest, apoptosis or senescence [43]. In support of this, recent studies have shown that $\mathrm{p} 53$ and its transcriptional target p21 (also known as CIP1/WAF1) suppress induced pluripotency [52-57]. These studies also indicate that reprogramming induces DNA DSBs that can also activate p53. Given that p53 is required to maintain genomic stability in both somatic and pluripotent stem cells, these findings raise concerns regarding the genomic stability of iPSCs (Figure 2).

Furthermore, although one study has identified very few genetic abnormalities in mouse iPSCs [58], recent genomic sequencing studies have identified coding sequence mutations in human iPSCs [59-61]. However, the origin of these genetic mutations, whether from pre-existing rare mutations or acquired during reprogramming, remains unclear. Recent SNP-CGH and genome sequencing studies have also identified chromosomal duplications and deletions in iPSCs, all of which are potentially oncogenic $[33,62,63]$. Such genetic abnormalities could cause other functional changes, such as immunogenicity of iPSC-derived cells. Therefore, to ensure the genetic stability of iPSCs, it is important to elucidate which p53dependent responses, such as cell cycle arrest, apoptosis and senescence, are important for protecting against reprogramming-induced DNA damage. The $\mathrm{p} 21$ protein is required for p53-dependent cell cycle arrest, and p53 upregulated modulator of apoptosis (PUMA) is required for p53-dependent apoptosis [64]. Depletion of PUMA and p21 greatly promotes reprogramming efficiency without increasing reprogramming-associated DNA damage by activating the senescence pathway [65]. Therefore, with improved understanding of the mechanisms involved in induced pluripotency and reprogramming-induced DNA damage responses, it may be possible to optimize reprogramming strategies to minimize the genetic instability in iPSCs.

\section{Risk of teratoma formation}

Pluripotent stem cells can form teratomas when transplanted in vivo $[1,66]$. The lineage-specific differentiation of hESCs or iPSCs is rarely complete, so a major hurdle that hinders the clinical application of hESC- or iPSCbased therapy is the risk of teratoma formation associated with the presence of undifferentiated hESCs or hiPSCs following transplantation [66]. This risk is further complicated by the intrinsic variability associated with lineage-specific differentiation of hESCs or hiPSCs. The risk of teratoma formation for hESC- or hiPSC-based cell

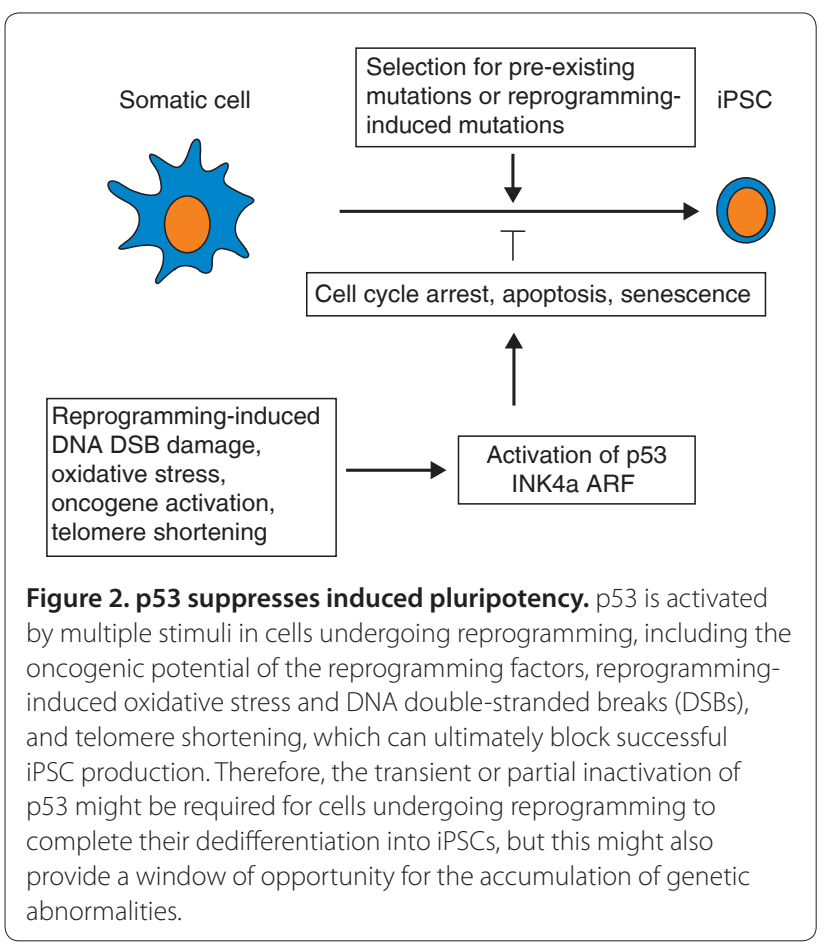

therapy would thus depend on the batch-to-batch variation in lineage-specific differentiation, and this could make evaluation of this risk a lengthy and costly process. An efficient and scalable approach to eliminate this risk would greatly facilitate the development of hESC- or hiPSC-based cell therapy.

Significant effort has been devoted to the development of antibody-based strategies for the removal of undifferentiated hESCs or iPSCs remaining in the differentiating culture before transplantation. For example, recent studies have shown that a cytotoxic antibody recognizing podocalyxin-like protein-1 (PODXL) can kill hESCs $[67,68]$. Recently, it has also been reported that immune depletion of hESCs using a combination of antibodies against multiple hESC surface markers (SSEA5, CD9, CD90 and CD200) can remove hESCs from differentiating cultures [69]. Although the expression of SSEA5 might be relatively specific for hESCs, other surface markers such as CD9, CD30, CD90 and CD200 are broadly expressed in differentiated tissues. Therefore, the limitation of these antibody-based strategies is the lack of specificity of the targeted hESC surface markers. In addition, it has been reported that the use of antibodybased approaches can be limited by the potential of some progenitor cells to spontaneously dedifferentiate into the pluripotent state after transplantation, leading to teratoma formation [70].

The pluripotent state of hESCs and hiPSCs is required for teratoma formation, so another approach to reduce the risk of teratoma formation by hESCs or hiPSCs is to 
inhibit pathways that are important for the pluripotency of hESCs or iPSCs. For example, recent studies have indicated that NANOG is required for the pluripotency of ESCs [71,72]. Strategies to suppress the expression of NANOG could therefore reduce the risk of teratoma formation. Accordingly, disruption of the interaction between NANOG and PIN1 results in destabilization of NANOG in ESCs and partially suppresses their potential for teratoma formation in vivo [73]. This finding suggests that, by targeting multiple pluripotency pathways, it could be possible to eliminate the risk of teratoma formation by hESCs or iPSCs.

\section{Immunogenicity of pluripotent stem cells}

Recent studies have investigated the immunogenicity of ESC- and iPSC-derived cells, as it is particularly important to avoid immune responses to these cells in clinical applications.

\section{Immunogenicity of ESC-derived cells}

ESCs express undetectable or very low levels of major histocompatibility complex (MHC) molecules, indicating that these cells are not immunogenic, although the expression levels of MHC molecules increase during the differentiation of ESCs [74]. Therefore, allogeneic immune responses would not be able to eliminate undifferentiated ESCs in transplants. Despite significant progress in the development of hESC-based cell therapies, a major issue that remains to be resolved is the immune rejection of hESC-derived cells by recipients because their derivatives express MHC molecules that are different from those of the recipients (Figure 3). Although allograft rejection can be delayed if the recipient's immune system is persistently suppressed, a significant fraction of allografts are still rejected within 5 years of transplantation [75]. In addition, long-term immunosuppression has serious adverse effects, such as increasing the risk of cancer and infection, especially in people chronically infected by cytomegalovirus, which make up 50 to $80 \%$ of the urban adult population in the US $[76,77]$. Therefore, in the course of developing hESC-based cell therapies, it is important to determine the risk/benefit ratio of therapies that require long-term immune suppression. It will greatly facilitate the development of hESC-based therapy if new effective approaches can be developed to induce immune tolerance to hESC-derived allogeneic cells without longterm systemic immune suppression.

Allogeneic immune rejection is primarily mediated by T-cell-dependent immune responses [74]. Several studies have suggested new strategies to induce immune tolerance of allografts by modulating the co-stimulatory pathways required for $\mathrm{T}$ cell activation, including the pathways involving cluster of differentiation 28 (CD28) and B7.1/2 (B7), CD40 and its ligand (CD40L, also known

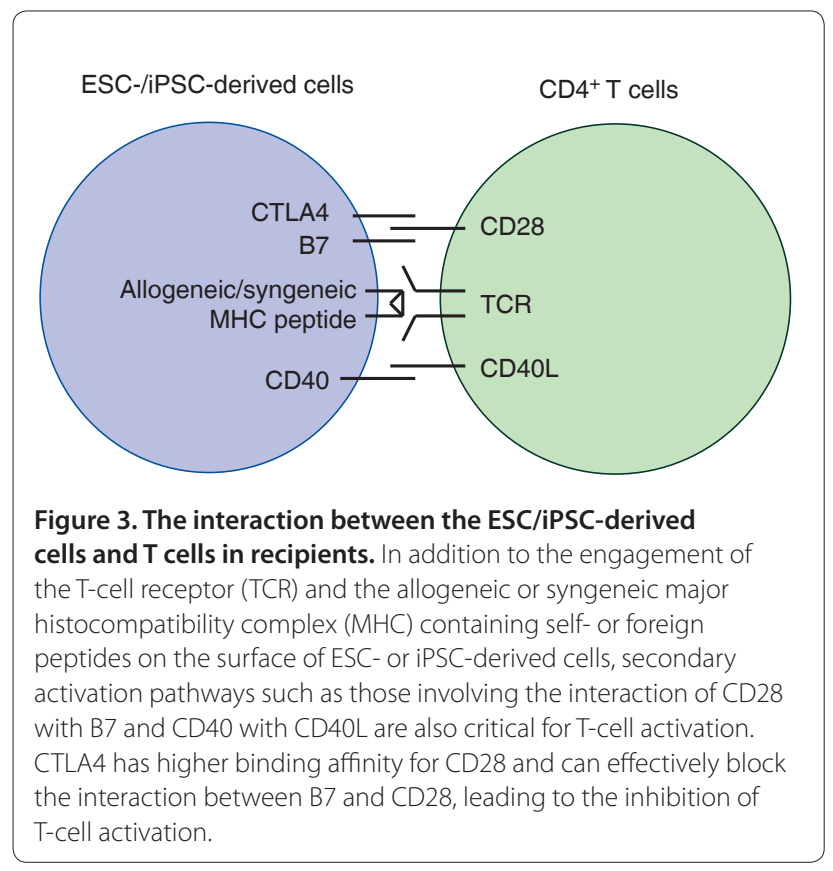

as CD154), or lymphocyte function-associated antigen 1 (LFA-1) and intercellular adhesion molecule 1 (ICAM-1) $[78,79]$. These co-stimulatory pathways are crucial for $\mathrm{T}$-cell activation, and in their absence $\mathrm{T}$ cells tolerate the antigen instead of being activated. For example, cytotoxic T-lymphocyte antigen 4 (CTLA4) disrupts the interaction between the $\mathrm{CD} 28$ and B7.1/2 proteins that is important for T-cell activation [80]. CTLA4-Ig, a secreted fusion protein that blocks the binding of B7 to CD28, can suppress autoimmunity and allograft rejection in experimental mouse models [81]. Recombinant CTLA4-Ig has been approved for treating patients with rheumatic arthritis and juvenile idiopathic arthritis [79]. Although data on the impact of co-stimulatory inhibition on allogeneic immune rejection in patients are lacking, xenograft transplantation experiments have shown that blocking co-stimulatory pathways with CTLA4-Ig, antiCD40L or anti-LFA-1 prolongs the survival of hESCderived xenografts in immune competent mice [82].

In addition to the disruption of co-stimulatory pathways, recent clinical studies have shown that infusion of bone marrow or HSCs from a donor into a recipient before the transplantation of allografts from the same donor can induce immune tolerance of allografts, probably by transiently establishing hematopoietic chimerism (in which hematopoietic cells come from both the donor and recipient) in the recipients and thus the immune tolerance of allografts from the donor [83]. Recent success in using mixed chimerism to induce long-term immune tolerance to renal transplantation in patients further supports the feasibility of this approach in inducing 
immune tolerance to allograft transplantation [84]. Therefore, it is possible that immune tolerance to hESCderived allogeneic cells could be achieved by the induction of hematopoietic chimerism in the recipient using HSCs derived from the same hESCs. However, although several studies have reported protocols to differentiate hESCs into potential multi-potent HSCs $[85,86]$, these potential HSCs have failed to repopulate the human immune system in vivo. The feasibility of inducing immune tolerance of hESC-derived allografts through hematopoietic chimerism depends on the successful derivation of authentic HSCs from hESCs. The identification of surface protein CD49f as a marker for human HSCs could facilitate the purification of hESCderived HSCs [87], and the recent discovery of the important roles of Sal-like protein 4 (SALL4) in promoting the self-renewal of HSCs might also help to expand hESC-derived HSCs [88]. Ectopic expression of SALL4 in human HSCs can lead to significant expansion of human HSCs in defined culture conditions.

\section{Immunogenicity of iPSC-derived cells}

iPSCs that have been reprogrammed from somatic cells of patients with defined factors could offer a key advantage in regenerative medicine as a renewable source of autologous cells for human cell therapy [89-92]. The initial success of iPSC production was achieved with retroviral vectors, but these vectors pose safety concerns for clinical application because the random integration of the retroviral vectors into the genome increases genomic instability [93]. In addition, the spontaneous re-expression of randomly integrated reprogramming factors, most of which have oncogenic potential, can pose a serious cancer risk [43]. Significant progress has been achieved in developing various approaches to produce integration-free hiPSCs, including the use of an episomal vector that can be maintained extrachromosomally in mammalian cells, and protein-based modified mRNA, miRNA and chemical biology approaches [94-100]. In addition, chemical biology approaches have been developed to improve reprogramming efficiency when combined with the standard reprogramming factors [99,101-105]. These approaches will improve the feasibility for clinical development of hiPSCs.

In one proof-of-principle study to demonstrate the use of iPSCs in autologous cell therapy, mouse iPSCs were reprogrammed from adult fibroblasts of a sickle cell anemia mouse model, and corrected for the causative genetic mutation by homologous recombination [106]. The corrected mouse iPSCs were then differentiated into HSCs that were transplanted back into the lethally irradiated mouse model to cure the disease [106]. More recent studies have also indicated the feasibility of using iPSC-derived cells to treat mouse models of hemophilia
A and liver degeneration in an immunodeficient background $[107,108]$. Although these studies demonstrate the functionality of iPSC-derived cells in vivo, their experimental design has not allowed the evaluation of the immunogenicity of iPSC-derived cells because the immune system of the recipients is either deficient or ablated by high dose irradiation.

To examine the immunogenicity of iPSC-derived cells, it would be ideal to differentiate iPSCs into various lineages of cells with therapeutic potential, which are then transplanted into syngeneic recipients. However, owing to the lack of physiologically relevant differentiation protocols and chemically defined conditions, it is possible that factors involved in the in vitro differentiation process itself might induce immune responses in syngeneic recipients $[109,110]$. It would therefore be difficult to determine whether any observed immunogenicity was intrinsic to the iPSC-derived cells or induced by the differentiation process. To resolve this issue, a recent study took advantage of the ability of ESCs and iPSCs to form teratomas in mice, enabling the simultaneous evaluation of the immunogenicity of various differentiated cell types, including terminally differentiated cell types such as muscle and pancreatic $\beta$ cells [111]. The feasibility of this approach was supported by the finding that C57BL/6 (B6) mice show immune tolerance for teratomas formed by B6 ESCs without any evidence of immune rejection, whereas teratomas formed by allogeneic ESCs undergo robust immune rejection in B6 mice. However, it was found that cells derived from B6 iPSCs can become immunogenic in syngeneic recipients through activation of antigen-specific T-cell-mediated immune responses [111]. Because there are few undifferentiated iPSCs in the formed teratomas, it appears that the observed T-cell response was directed against the cells differentiated from iPSCs. Therefore, the T-celldependent immune responses directed against the iPSCderived grafts appeared to have been activated as a result of the abnormal expression of immunogenic proteins during iPSC differentiation. Furthermore, despite the great similarity in global gene expression between ESCs and iPSCs [89-92], recent whole-genome bisulfite sequencing studies have identified abnormal epigenetics in iPSCs [112-114]. Therefore, although remaining to be confirmed, the abnormal epigenetics of iPSCs could contribute to abnormal gene expression and immunogenicity during differentiation of iPSCs. However, the immunogenicity of lineage-specific cells differentiated from iPSCs in vitro remains to be evaluated.

\section{Conclusions and future directions}

Tremendous progress has led to the initiation of clinic trials of two hESC-based cell therapies for spinal cord injury and macular degeneration. However, several major 
hurdles remain for the clinical development of hESCbased therapies, including those currently undergoing clinical trial. For example, it is crucial to elucidate the pathways that are important to maintain the genomic stability of hESCs during their long-term expansion and lineage-specific differentiation. In addition, efficient and scalable approaches to remove undifferentiated hESCs from their derivatives are needed to eliminate the risk of teratoma formation associated with pluripotent stem cells. Considering the severe adverse side effects of chronic systemic immune suppression, the risk/benefit ratio of hESC-based cell therapy must be carefully evaluated. Therefore, the development of novel approaches to protect hESC-derived cells from allogeneic immune rejection will greatly improve the feasibility to develop hESC-based cell therapies. In this context, the optimization of humanized mouse models with a functional human immune system will be important for developing and evaluating new approaches to induce immune tolerance to hESC-derived allografts.

Although hiPSCs have become a valuable tool for modeling human diseases and for drug discovery, the development of hiPSCs for cell therapy has been challenged by the recent discovery of epigenetic and genetic abnormalities associated with induced pluripotency. The immunogenicity of cells derived from human iPSCs remains to be vigorously examined in the context of an autologous human immune system. Therefore, a key challenge for the clinical development of iPSCs is to understand the mechanisms underlying induced pluripotency so as to optimize reprogramming conditions and minimize genetic and epigenetic abnormalities. Recent findings have supported the feasibility of achieving this goal. Hypoxic conditions and small molecules that promote anaerobic metabolism can also promote reprogramming $[99,115]$. Reactive oxidative stress, a byproduct of oxidative phosphorylation during aerobic metabolism, has been considered to be a major inducer of genomic mutations [116], so hypoxic conditions or compounds that suppress oxidative phosphorylation might reduce the genomic instability of iPSCs. In addition, elucidating the roles of tumor suppressors in induced pluripotency could also facilitate the development of strategies to reduce the genomic instability associated with iPSCs.

The epigenetic state of pluripotent stem cells derived by somatic nuclear transfer appears to be more similar to that of ESCs than the epigenetic state of iPSCs is to that of ESCs [117]. This raises the possibility that the epigenetic differences between ESCs and iPSCs could be minimized by including additional oocyte-specific factors in the reprogramming cocktail. In addition, several small molecules that are known to regulate the activities of enzymes involved in epigenetics can also increase reprogramming efficiency. It is therefore possible that epigenetic differences between ESCs and iPSCs could be minimized by the addition of these small molecules in reprogramming cocktails [118].

Genomic approaches will continue to be crucial in evaluating the genomic and epigenomic stability of pluripotent stem cells. These approaches will need to be performed alongside functional analyses to facilitate a better understanding of the functional stability of these cells and their clinical utility. Rapid progress in genomic approaches and in understanding human pluripotent stem cell biology suggests that the challenges discussed here that might hinder the development of pluripotent stem cell-based therapy can be overcome.

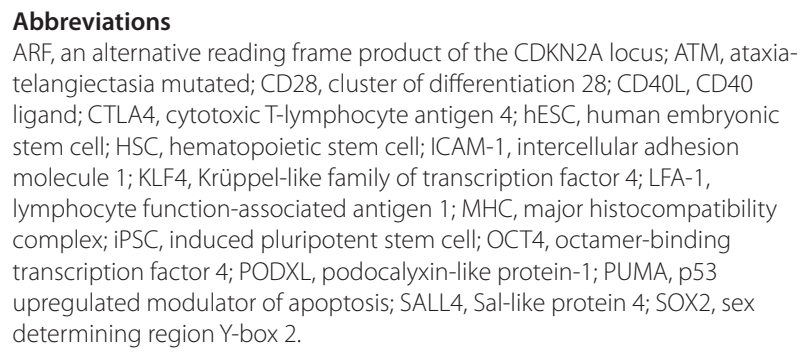

Competing interests

The authors declare that they have no competing interests.

\section{Acknowledgements}

This work was supported by a grant from NSFC to XF (81172828) and a grant from the California Institute for Regenerative Medicine (CIRM) to YX (TR1-01277).

Published: 28 June 2012

\section{References}

1. Thomson JA, Itskovitz-Eldor J, Shapiro SS, Waknitz MA, Swiergiel JJ, Marshall VS, Jones JM: Embryonic stem cell lines derived from human blastocysts. Science 1998, 282:1145-1147.

2. Laflamme MA, Chen KY, Naumova AV, Muskheli V, Fugate JA, Dupras SK, Reinecke H, Xu C, Hassanipour M, Police S, O'Sullivan C, Collins L, Chen Y, Minami E, Gill EA, Ueno S, Yuan C, Gold J, Murry CE: Cardiomyocytes derived from human embryonic stem cells in pro-survival factors enhance function of infarcted rat hearts. Nat Biotechnol 2007, 25:1015-1024.

3. Xu C, Police S, Hassanipour M, Li Y, Chen Y, Priest C, O'Sullivan C, Laflamme MA, Zhu WZ, Van Biber B, Hegerova L, Yang J, Delavan-Boorsma K, Davies A, Lebkowski J, Gold JD: Efficient generation and cryopreservation of cardiomyocytes derived from human embryonic stem cells. Regen Med 2010, 6:53-66.

4. Marzorati S, Pileggi A, Ricordi C: Allogeneic islet transplantation. Expert Opin Biol Ther 2007, 7:1627-1645.

5. D'Amour KA, Bang AG, Eliazer S, Kelly OG, Agulnick AD, Smart NG, Moorman MA, Kroon E, Carpenter MK, Baetge EE: Production of pancreatic hormoneexpressing endocrine cells from human embryonic stem cells. Nat Biotechno/ 2006, 24:1392-1401.

6. Kroon E, Martinson LA, Kadoya K, Bang AG, Kelly OG, Eliazer S, Young H, Richardson M, Smart NG, Cunningham J, Agulnick AD, D'Amour KA, Carpenter MK, Baetge EE: Pancreatic endoderm derived from human embryonic stem cells generates glucose-responsive insulin-secreting cells in vivo. Nat Biotechnol 2008, 26:443-452.

7. Coutts M, Keirstead HS: Stem cells for the treatment of spinal cord injury. Exp Neurol 2008, 209:368-377.

8. Solbakk JH, Zoloth $L$ : The tragedy of translation: the case of 'first use' in human embryonic stem cell research. Cell Stem Cell 2011, 8:479-481.

9. Schwartz SD, Hubschman J-P, Heilwell G, Franco-Cardenas V, Pan CK, Ostrick 
RM, Mickunas E, Gay R, Klimanskaya I, Lanza R: Embryonic stem cell trials for macular degeneration: a preliminary report. Lancet 2012, 379:713-720.

10. Lewitzky M, Yamanaka S: Reprogramming somatic cells towards pluripotency by defined factors. Curr Opin Biotechnol 2007, 18:467-473.

11. Fu $X, X u Y$ : Self-renewal and scalability of human embryonic stem cells for human therapy. Regen Med 2011, 6:327-334.

12. Si Y-L, Zhao Y-L, Hao H-J, Fu X-B, Han W-D: MSCs: biological characteristics, clinical applications and their outstanding concerns. Ageing Res Rev 2011, 10:93-103.

13. Lunn JS, Sakowski SA, Federici T, Glass JD, Boulis NM, Feldman EL: Stem cell technology for the study and treatment of motor neuron diseases. Regen Med 2011, 6:201-213

14. Mitjavila-Garcia MT, Simonin Cm, Peschanski M: Embryonic stem cells: Meeting the needs for cell therapy. Adv Drug Deliv Rev 2005, 57:1935-1943.

15. Crook JM, Peura TT, Kravets L, Bosman AG, Buzzard JJ, Horne R, Hentze H, Dunn NR, Zweigerdt R, Chua F, Upshall A, Colman A: The generation of six clinical-grade human embryonic stem cell lines. Cell Stem Cell 2007, 1:490-494.

16. Sivarajah S, Raj GS, Mathews AJV, Sahib NBE, Hwang WS, Crook JM: The generation of GLP-grade human embryonic stem cell banks from four clinical-grade cell lines for preclinical research. In Vitro Cell Dev Biol Anim 2010, 46:210-216.

17. Englund MCO, Caisander G, Noaksson K, Emanuelsson K, Lundin K, Bergh C, Hansson C, Semb H, Strehl R, Hyllner J: The establishment of 20 different human embryonic stem cell lines and subclones; a report on derivation, culture, characterisation and banking. In Vitro Cell Dev Biol Anim 2010, 46:217-230.

18. Aguilar-Gallardo C, Poo M, Gomez E, Galan A, Sanchez E, Marques-Mari A, Ruiz V, Medrano J, Riboldi M, Valbuena D, Simon C: Derivation, characterization, differentiation, and registration of seven human embryonic stem cell lines (VAL-3,-4,-5,-6M,-7,-8, and-9) on human feeder. In Vitro Cell Dev Biol Anim 2010, 46:317-326.

19. Meng GLL Liu SY, Krawetz R, Chan M, Chernos J, Rancourt DE: A novel method for generating xeno-free human feeder cells for human embryonic stem cell culture. Stem Cells Dev 2008, 17:413-422.

20. Tecirlioglu RT, Nguyen L, Koh K, Trounson AO, Michalska AE: Derivation and maintenance of human embryonic stem cell line on human adult skin fibroblast feeder cells in serum replacement medium. In Vitro Cell Dev Biol Anim 2010, 46:231-235.

21. Park Y, Choi IY, Lee SJ, Lee SR, Sung HJ, Kim JH, Yoo YD, Geum DH, Kim SH, Kim BS: Undifferentiated propagation of the human embryonic stem cell lines, $\mathrm{H} 1$ and $\mathrm{HSF} 6$, on human placenta-derived feeder cells without basic fibroblast growth factor supplementation. Stem Cells Dev 2010, 19:1713-1722.

22. Meng GL, Liu SY, Li XY, Krawetz R, Rancourt DE: Extracellular matrix isolated from foreskin fibroblasts supports long-term xeno-free human embryonic stem cell culture. Stem Cells Dev 2010, 19:547-556.

23. Meng Y, Eshghi S, Li YJ, Schmidt R, Schaffer DV, Healy KE: Characterization of integrin engagement during defined human embryonic stem cell culture. FASEB J 2010, 24:1056-1065

24. Rodin S, Domogatskaya A, Strom S, Hansson EM, Chien KR, Inzunza J, Hovatta $\mathrm{O}$, Tryggvason K: Long-term self-renewal of human pluripotent stem cells on human recombinant laminin-511. Nat Biotechno/ 2010, 28:611-615.

25. Prowse ABJ, Doran MR, Cooper-White JJ, Chong F, Munro TP, Fitzpatrick J, Chung T-L, Haylock DN, Gray PP, Wolvetang EJ: Long term culture of human embryonic stem cells on recombinant vitronectin in ascorbate free media. Biomaterials 2010, 31:8281-8288.

26. Ludwig TE, Bergendahl V, Levenstein ME, Yu J, Probasco MD, Thomson JA: Feeder-independent culture of human embryonic stem cells. Nat Methods 2006, 3:637-646

27. Wang L, Schulz TC, Sherrer ES, Dauphin DS, Shin S, Nelson AM, Ware CB, Zhan M, Song C-Z, Chen X, Brimble SN, McLean A, Galeano MJ, Uhl EW, D'Amour KA, Chesnut JD, Rao MS, Blau CA, Robins AJ: Self-renewal of human embryonic stem cells requires insulin-like growth factor-1 receptor and ERBB2 receptor signaling. Blood 2007, 110:4111-4119.

28. Yao S, Chen S, Clark J, Hao E, Beattie GM, Hayek A, Ding S: Long-term selfrenewal and directed differentiation of human embryonic stem cells in chemically defined conditions. Proc Natl Acad Sci U S A 2006, 103:6907-6912.

29. Melkoumian Z, Weber JL, Weber DM, Fadeev AG, Zhou YE, Dolley-Sonneville P, Yang JW, Qiu LQ, Priest CA, Shogbon C, Melkoumian Z, Weber JL, Weber DM, Fadeev AG, Zhou YE, Dolley-Sonneville P, Yang JW, Qiu LQ, Priest CA,
Shogbon C: Synthetic peptide-acrylate surfaces for long-term self-renewal and cardiomyocyte differentiation of human embryonic stem cells. Nat Biotechnol 2010, 28:606-610

30. Villa-Diaz LG, Nandivada H, Ding J, Nogueira-De-Souza NC, Krebsbach PH, O'Shea KS, Lahann J, Smith GD: Synthetic polymer coatings for long-term growth of human embryonic stem cells. Nat Biotechnol 2010, 28:581-583.

31. Serra M, Brito C, Sousa MFQ, Jensen J, Tostıes R, Clemente Jo, Strehl R, Hyllner J, Carrondo MJT, Alves PM: Improving expansion of pluripotent human embryonic stem cells in perfused bioreactors through oxygen control. J Biotechnol 2010, 148:208-215.

32. Steiner D, Khaner H, Cohen M, Even-Ram S, Gil Y, Itsykson P. Turetsky T, Idelson M, Aizenman E, Ram R, Berman-Zaken Y, Reubinoff B: Derivation, propagation and controlled differentiation of human embryonic stem cells in suspension. Nat Biotechnol 2010, 28:361-388.

33. Laurent LC, Ulitsky I, Slavin I, Tran H, Schork A, Morey R, Lynch C, Harness JV, Lee S, Barrero MJ, Ku S, Martynova M, Semechkin R, Galat V, Gottesfeld J, Izpisua Belmonte JC, Murry C, Keirstead HS, Park HS, Schmidt U, Laslett AL, Muller FJ, Nievergelt CM, Shamir R, Loring JF: Dynamic changes in the copy number of pluripotency and cell proliferation genes in human ESCs and iPSCs during reprogramming and time in culture. Cell Stem Cell 2011, 8:106-118

34. Xu Y: A new role for $\mathrm{p} 53$ in maintaining genetic stability in embryonic stem cells. Cell Cycle 2005, 4:363-364.

35. XuY: DNA damage: a trigger of innate immunity but a requirement for adaptive immune homeostasis. Nat Rev Immuno/ 2006, 6:261-270.

36. Song $H$, Chung SK, Xu Y: Modeling disease in human ESCs using an efficient BAC-based homologous recombination system. Cell Stem Cell 2010, 6:80-89.

37. Vousden $\mathrm{KH}$, Prives $\mathrm{C}$ : Blinded by the light: the growing complexity of $\mathrm{p} 53$. Cell 2009, 137:413-431

38. Feng Z, Hu W, Rajagopal G, Levine AJ: The tumor suppressor p53: cancer and aging. Cell Cycle 2008, 7:842-847.

39. Suzuki H, Miyazono K: Dynamics of microRNA biogenesis: crosstalk between p53 network and microRNA processing pathway. J Mol Med 2010, 88:1085-1094.

40. Momcilovic O, Choi S, Varum S, Bakkenist C, Schatten G, Navara C: lonizing radiation induces ataxia telangiectasia mutated-dependent checkpoint signaling and cell cycle arrest in pluripotent human embryonic stem cells. Stem Cells 2009, 27:1822-1835.

41. Song $H$, Chung S-K, XU Y: Modeling disease in human ESCs using an efficient BAC-based homologous recombination system. Cell Stem Cell 2010, 6:80-89.

42. Lin T, Chao C, Saito S, Mazur SJ, Murphy ME, Appella E, Xu Y: p53 induces differentiation of mouse embryonic stem cells by suppressing Nanog expression. Nat Cell Biol 2005, 7:165-171.

43. Zhao T, Xu Y: p53 and stem cells: new developments and new concerns. Trends Cell Biol 2010, 20:170-175

44. Pelengaris S, Khan M, Evan G: c-MYC: more than just a matter of life and death. Nat Rev Cancer 2002, 2:764-776.

45. Rowland BD, Peeper DS: KLF4, p21 and context-dependent opposing forces in cancer. Nat Rev Cancer 2006, 6:11-23.

46. Almstrup K, Hoei-Hansen CE, Wirkner U, Blake J, Schwager C, Ansorge W, Nielsen JE, Skakkebaek NE, Rajpert-De Meyts E, Leffers H: Embryonic stem cell-like features of testicular carcinoma in situ revealed by genome-wide gene expression profiling. Cancer Res 2004, 64:4736-4743.

47. Hochedlinger K, Yamada Y, Beard C, Jaenisch R: Ectopic expression of Oct-4 blocks progenitor-cell differentiation and causes dysplasia in epithelial tissues. Cell 2005, 121:465-477.

48. Ezeh UI, Turek PJ, Reijo RA, Clark AT: Human embryonic stem cell genes OCT4, NANOG, STELLAR, and GDF3 are expressed in both seminoma and breast carcinoma. Cancer 2005, 104:2255-2265

49. Hart AH, Hartley L, Parker K, Ibrahim M, Looijenga LH, Pauchnik M, Chow CW, Robb L: The pluripotency homeobox gene NANOG is expressed in human germ cell tumors. Cancer 2005, 104:2092-2098.

50. West JA, Viswanathan SR, Yabuuchi A, Cunniff K, Takeuchi A, Park I-H, Sero JE, Zhu H, Perez-Atayde A, Frazier AL, Surani MA, Daley GQ: A role for Lin28 in primordial germ-cell development and germ-cell malignancy. Nature 2009, 460:909-913.

51. Viswanathan SR, Daley GQ, Gregory RI: Selective blockade of microRNA processing by Lin28. Science 2008, 320:97-100.

52. Zhao Y, Yin X, Qin H, Zhu F, Liu H, Yang W, Zhang Q, Xiang C, Hou P, Song Z, 
Liu Y, Yong J, Zhang P, Cai J, Liu M, Li H, Li Y, Qu X, Cui K, Zhang W, Xiang T, Wu Y, Zhao Y, Liu C, Yu C, Yuan K, Lou J, Ding M, Deng H: Two supporting factors greatly improve the efficiency of human iPSC generation. Cell Stem Cell 2008, 3:475-479

53. Li H, Collado M, Villasante A, Strati K, Ortega S, Canamero M, Blasco MA, Serrano M: The Ink4/Arf locus is a barrier for iPS cell reprogramming. Nature 2009, 460:1136-1139.

54. Kawamura T, Suzuki J, Wang YV, Menendez S, Morera LB, Raya A, Wahl GM, Belmonte JC: Linking the p53 tumour suppressor pathway to somatic cell reprogramming. Nature 2009, 460:1140-1144.

55. Marion RM, Strati K, Li H, Murga M, Blanco R, Ortega S, Fernandez-Capetillo O, Serrano M, Blasco MA: A p53-mediated DNA damage response limits reprogramming to ensure iPS cell genomic integrity. Nature 2009, 460:1149-1153

56. Utikal J, Polo JM, Stadtfeld M, Maherali N, Kulalert W, Walsh RM, Khalil A, Rheinwald JG, Hochedlinger K: Immortalization eliminates a roadblock during cellular reprogramming into iPS cells. Nature 2009, 460:1145-1148.

57. Hong H, Takahashi K, Ichisaka T, Aoi T, Kanagawa O, Nakagawa M, Okita K, Yamanaka S: Suppression of induced pluripotent stem cell generation by the p53-p21 pathway. Nature 2009, 460:1132-1135.

58. Quinlan AR, Boland MJ, Leibowitz ML, Shumilina S, Pehrson SM, Baldwin KK, Hall IM: Genome sequencing of mouse induced pluripotent stem cells reveals retroelement stability and infrequent DNA rearrangement during reprogramming. Cell Stem Cell 2011, 9:366-373.

59. Ji J, Ng SH, Sharma V, Neculai D, Hussein S, Sam M, Trinh Q, Church GM, McPherson JD, Nagy A, Batada NN: Elevated coding mutation rate during the reprogramming of human somatic cells into induced pluripotent stem cells. Stem Cells 2012, 30:435-440.

60. Pasi CE, Dereli-Oz A, Negrini S, Friedli M, Fragola G, Lombardo A, Van Houwe G, Naldini L, Casola S, Testa G, Pasi CE, Dereli-Oz A, Negrini S, Friedli M, Fragola G, Lombardo A, Van Houwe G, Naldini L, Casola S, Testa G: Genomic instability in induced stem cells. Cell Death Differ 2011, 18:745-753.

61. Cheng L, Hansen NF, Zhao L, Du Y, Zou C, Donovan FX, Chou B-K, Zhou G, Li S, Dowey SN, Ye Z; NISC Comparative Sequencing Program, Chandrasekharappa SC, Yang H, Mullikin JC, Liu PP: Low incidence of DNA sequence variation in human induced pluripotent stem cells generated by nonintegrating plasmid expression. Cell Stem Cell 2012, 10:337-344.

62. Hussein SM, Batada NN, Vuoristo S, Ching RW, Autio R, Närvä E, Ng S, Sourour M, Hämäläinen R, Olsson C, Lundin K, Mikkola M, Trokovic R, Peitz M, Brüstle O, Bazett-Jones DP, Alitalo K, Lahesmaa R, Nagy A, Otonkoski T: Copy number variation and selection during reprogramming to pluripotency. Nature 2011, 471:58-62.

63. Mayshar Y, Ben-David U, Lavon N, Biancotti J-C, Yakir B, Clark AT, Plath K, Lowry WE, Benvenisty N: Identification and classification of chromosomal aberrations in human induced pluripotent stem cells. Cell Stem Cell 2010, 7:521-531.

64. Michalak E, Villunger A, Erlacher M, Strasser A: Death squads enlisted by the tumour suppressor p53. Biochem Biophys Res Commun 2005, 331:786-798.

65. Lake BB, Fink J, Klemetsaune L, Fu X, Jeffers JR, Zambetti GP, Xu Y: Contextdependent enhancement of induced pluripotent stem cell reprogramming by silencing Puma. Stem Cells 2012, 30:888-897.

66. Ben-David U, Benvenisty N: The tumorigenicity of human embryonic and induced pluripotent stem cells. Nat Rev Cancer 2011, 11:268-277.

67. Choo AB, Tan HL, Ang SN, Fong WJ, Chin A, Lo J, Zheng L, Hentze H, Philp RJ, Oh SK, Yap M: Selection against undifferentiated human embryonic stem cells by a cytotoxic antibody recognizing podocalyxin-like protein-1. Stem Cells 2008, 26:1454-1463.

68. Tan HL, Fong WJ, Lee EH, Yap M, Choo A: mAb 84, a cytotoxic antibody that kills undifferentiated human embryonic stem cells via oncosis. Stem Cells 2009, 27:1792-1801.

69. Tang C, Lee AS, Volkmer J-P, Sahoo D, Nag D, Mosley AR, Inlay MA, Ardehali R, Chavez SL, Pera RR, Behr B, Wu JC, Weissman IL, Drukker M: An antibody against SSEA-5 glycan on human pluripotent stem cells enables removal of teratoma-forming cells. Nat Biotechnol 2011, 29:829-834.

70. Fujikawa T, Oh S-H, Pi L, Hatch HM, Shupe T, Petersen BE: Teratoma formation leads to failure of treatment for type I diabetes using embryonic stem cell-derived insulin-producing cells. Am J Pathol 2005, 166:1781-1791.

71. Chambers I, Colby D, Robertson M, Nichols J, Lee S, Tweedie S, Smith A: Functional expression cloning of Nanog, a pluripotency sustaining factor in embryonic stem cells. Cell 2003, 113:643-655.

72. Mitsui K, Tokuzawa Y, Itoh H, Segawa K, Murakami M, Takahashi K, Maruyama
M, Maeda M, Yamanaka S: The homeoprotein Nanog is required for maintenance of pluripotency in mouse epiblast and ES cells. Cell 2003, 113:631-642.

73. Moretto-Zita M, Jin H, Shen Z, Zhao T, Briggs SP, Xu Y: Phosphorylation stabilizes Nanog by promoting its interaction with Pin1. Proc Natl Acad SCi USA 2010, 107:13312-13317.

74. Boyd AS, Rodrigues NP, Lui KO, Fu X, Xu Y: Concise review: immune recognition of induced pluripotent stem cells. Stem Cells 2012, 30:797-803.

75. Stucker F, Marti HP, Hunger RE: Immunosuppressive drugs in organ transplant recipients--rationale for critical selection. Curr Probl Dermatol 2012, 43:36-48.

76. Schonder KS, Mazariegos GV, Weber RJ: Adverse effects of immunosuppression in pediatric solid organ transplantation. Pediatric Drugs 2010, 12:35-49

77. Baron C, Forconi C, Lebranchu Y: Revisiting the effects of CMV on long-term transplant outcome. Curr Opin Organ Transplant 2010, 15:492-498.

78. Lebedeva T, Dustin ML, Sykulev Y: ICAM-1 co-stimulates target cells to facilitate antigen presentation. Curr Opin Immunol 2005, 17:251-258.

79. Felix NJ, Suri A, Salter-Cid L, Nadler SG, Gujrathi S, Corbo M, Aranda R: Targeting lymphocyte co-stimulation: From bench to bedside. Autoimmunity 2010, 43:514-525.

80. Isaacs JD: T cell immunomodulation, the Holy Grail of therapeutic tolerance. Curr Opin Pharmacol 2007, 7:418-425.

81. Fife BT, Bluestone JA: Control of peripheral T-cell tolerance and autoimmunity via the CTLA-4 and PD-1 pathways. Immunol Rev 2008, 224:166-182.

82. Pearl Jl, Lee AS, Leveson-Gower DB, Sun N, Ghosh Z, Lan F, Ransohoff J Negrin RS, Davis MM, Wu JC: Short-term immunosuppression promotes engraftment of embryonic and induced pluripotent stem cells. Cell Stem Cell 2010, 8:309-317.

83. Turka LA, Wood K, Bluestone JA: Bringing transplantation tolerance into the clinic: lessons from the ITN and RISET for the Establishment of Tolerance consortia. Curr Opin Organ Transplant 2010, 15:441-448.

84. Scandling JD, Busque S, Dejbakhsh-Jones S, Benike C, Millan MT, Shizuru JA, Hoppe RT, Lowsky R, Engleman EG, Strober S: Tolerance and chimerism after renal and hematopoietic-cell transplantation. N Engl J Med 2008, 358:362-368.

85. Vodyanik MA, Bork JA, Thomson JA, Slukvin II: Human embryonic stem cellderived CD34+ cells: efficient production in the coculture with OP9 stromal cells and analysis of lymphohematopoietic potential. Blood 2005, 105:617-626.

86. Ledran MH, Krassowska A, Armstrong L, Dimmick I, Renström J, Lang R, Yung S, Santibanez-Coref M, Dzierzak E, Stojkovic M, Oostendorp RA, Forrester L, Lako M: Efficient hematopoietic differentiation of human embryonic stem cells on stromal cells derived from hematopoietic niches. Cell Stem Cell 2008, 3:85-98.

87. Notta F, Doulatov S, Laurenti E, Poeppl A, Jurisica I, Dick JE: Isolation of single human hematopoietic stem cells capable of long-term multilineage engraftment. Science 2011, 333:218-221.

88. Aguila JR, Liao W, Yang J, Avila C, Hagag N, Senzel L, Ma Y: SALL4 is a robust stimulator for the expansion of hematopoietic stem cells. Blood 2011, 118:576-585.

89. Takahashi K, Yamanaka S: Induction of pluripotent stem cells from mouse embryonic and adult fibroblast cultures by defined factors. Cell 2006, 126:663-676.

90. Takahashi K, Tanabe K, Ohnuki M, Narita M, Ichisaka T, Tomoda K, Yamanaka S: Induction of pluripotent stem cells from adult human fibroblasts by defined factors. Cell 2007, 131:861-872.

91. Yu J, Vodyanik MA, Smuga-Otto K, Antosiewicz-Bourget J, Frane JL, Tian S, Nie J, Jonsdottir GA, Ruotti V, Stewart R, Slukvin II, Thomson JA: Induced pluripotent stem cell lines derived from human somatic cells. Science 2007, 318:1917-1920.

92. Park I-H, Zhao R, West JA, Yabuuchi A, Huo H, Ince TA, Lerou PH, Lensch MW, Daley GQ: Reprogramming of human somatic cells to pluripotency with defined factors. Nature 2008, 451:141-146.

93. Yamanaka S: A fresh look at iPS cells. Cell 2009, 137:13-17.

94. Yu J, Hu K, Smuga-Otto K, Tian S, Stewart R, Slukvin, II, Thomson JA: Human induced pluripotent stem cells free of vector and transgene sequences. Science 2009, 324:797-801.

95. Zhou H, Wu S, Joo JY, Zhu S, Han DW, Lin T, Trauger S, Bien G, Yao S, Zhu Y, Siuzdak G, Schöler HR, Duan L, Ding S: Generation of induced pluripotent 
stem cells using recombinant proteins. Cell Stem Cell 2009, 4:381-384.

96. Warren L, Manos PD, Ahfeldt T, Loh Y-H, Li H, Lau F, Ebina W, Mandal PK, Smith ZD, Meissner A, Daley GQ, Brack AS, Collins JJ, Cowan C, Schlaeger TM, Rossi DJ: Highly efficient reprogramming to pluripotency and directed differentiation of human cells with synthetic modified mRNA. Cell Stem Cell 2010, 7:618-630.

97. Miyoshi N, Ishii H, Nagano H, Haraguchi N, Dewi DL, Kano Y, Nishikawa S, Tanemura M, Mimori K, Tanaka F, Saito T, Nishimura J, Takemasa I, Mizushima T, Ikeda M, Yamamoto H, Sekimoto M, Doki Y, Mori M: Reprogramming of mouse and human cells to pluripotency using mature microRNAs. Cell Stem Cell 2010, 8:633-638.

98. Anokye-Danso F, Trivedi CM, Juhr D, Gupta M, Cui Z, Tian Y, Zhang Y, Yang W, Gruber PJ, Epstein JA, Morrisey EE: Highly efficient miRNA-mediated reprogramming of mouse and human somatic cells to pluripotency. Cell Stem Cell 2010, 8:376-388.

99. Zhu S, Li W, Zhou H, Wei W, Ambasudhan R, Lin T, Kim J, Zhang K, Ding S: Reprogramming of human primary somatic cells by OCT4 and chemical compounds. Cell Stem Cell 2010, 7:651-655.

100. Zhao T, Zhang Z-N, Rong Z, Xu Y: Immunogenicity of induced pluripotent stem cells. Nature 2011, 474:212-215.

101. Shi Y, Desponts C, Do JT, Hahm HS, Schöler HR, Ding S: Induction of pluripotent stem cells from mouse embryonic fibroblasts by Oct4 and KIf4 with small-molecule compounds. Cell Stem Cell 2008, 3:568-574.

102. Huangfu D, Osafune K, Maehr R, Guo W, Eijkelenboom A, Chen S, Muhlestein W, Melton DA: Induction of pluripotent stem cells from primary human fibroblasts with only Oct4 and Sox2. Nat Biotechnol 2008, 26:1269-1275.

103. Lin T, Ambasudhan R, Yuan X, Li W, Hilcove S, Abujarour R, Lin X, Hahm HS, Hao E, Hayek A, Ding S: A chemical platform for improved induction of human iPSCs. Nat Methods 2009, 6:805-808.

104. Esteban MA, Wang T, Qin B, Yang J, Qin D, Cai J, Li W, Weng Z, Chen J, Ni S, Chen K, Li Y, Liu X, Xu J, Zhang S, Li F, He W, Labuda K, Song Y, Peterbauer A, Wolbank S, Redl H, Zhong M, Cai D, Zeng L, Pei D: Vitamin C enhances the generation of mouse and human induced pluripotent stem cells. Cell Stem Cell 2010, 6:71-79

105. Wang Q, Xu X, Li J, Liu J, Gu H, Zhang R, Chen J, Kuang Y, Fei J, Jiang C, Wang P, Pei $D$, Ding S, Xie X: Lithium, an anti-psychotic drug, greatly enhances the generation of induced pluripotent stem cells. Cell Res 2011, 21:1424-1435.

106. Hanna J, Wernig M, Markoulaki S, Sun CW, Meissner A, Cassady JP, Beard C, Brambrink T, Wu LC, Townes TM, Jaenisch R: Treatment of sickle cell anemia mouse model with iPS cells generated from autologous skin. Science 2007, 318:1920-1923.

107. Xu D, Alipio Z, Fink LM, Adcock DM, Yang J, Ward DC, Ma Y: Phenotypic correction of murine hemophilia A using an iPS cell-based therapy. Proc Natl Acad Sci USA 2009, 106:808-813.

108. Liu H, Kim Y, Sharkis S, Marchionni L, Jang Y-Y: In vivo liver regeneration potential of human induced pluripotent stem cells from diverse origins. SciTransl Med 2011, 3:82ra39.
109. Swijnenburg R-J, Tanaka M, Vogel H, Baker J, Kofidis T, Gunawan F, Lebl DR, Caffarelli AD, de Bruin JL, Fedoseyeva EV, Robbins RC: Embryonic stem cell immunogenicity increases upon differentiation after transplantation into ischemic myocardium. Circulation 2005, 112:-1-166-172.

110. Robertson NJ, Brook FA, Gardner RL, Cobbold SP, Waldmann H, Fairchild PJ: Embryonic stem cell-derived tissues are immunogenic but their inherent immune privilege promotes the induction of tolerance. Proc Natl Acad Sci US A 2007, 104:20920-20925.

111. Zhao T, Zhang ZN, Rong Z, Xu Y: Immunogenicity of induced pluripotent stem cells. Nature 2011, 474:212-215.

112. Doi A, Park IH, Wen B, Murakami P, Aryee MJ, Irizarry R, Herb B, Ladd-Acosta C, Rho J, Loewer S, Miller J, Schlaeger T, Daley GQ, Feinberg AP: Differential methylation of tissue- and cancer-specific CpG island shores distinguishes human induced pluripotent stem cells, embryonic stem cells and fibroblasts. Nat Genet 2009, 41:1350-1353.

113. Deng J, Shoemaker R, Xie B, Gore A, LeProust EM, Antosiewicz-Bourget J, Egli D, Maherali N, Park I-H, Yu J, Daley GQ, Eggan K, Hochedlinger K, Thomson J, Wang W, Gao Y, Zhang K: Targeted bisulfite sequencing reveals changes in DNA methylation associated with nuclear reprogramming. Nat Biotechnol 2009, 27:353-360.

114. Lister R, Pelizzola M, Kida YS, Hawkins RD, Nery JR, Hon G, AntosiewiczBourget J, O'Malley R, Castanon R, Klugman S, Downes M, Yu R, Stewart R, Ren B, Thomson JA, Evans RM, Ecker JR: Hotspots of aberrant epigenomic reprogramming in human induced pluripotent stem cells. Nature 2011, 471:68-73.

115. Yoshida Y, Takahashi K, Okita K, Ichisaka T, Yamanaka S: Hypoxia enhances the generation of induced pluripotent stem cells. Cell Stem Cell 2009, 5:237-241.

116. Liu D, Xu Y: p53, oxidative stress, and aging. Antioxid Redox Signal 2011, 15:1669-1678

117. Stadtfeld M, Apostolou E, Akutsu H, Fukuda A, Follett P, Natesan S, Kono T, Shioda T, Hochedlinger K: Aberrant silencing of imprinted genes on chromosome 12qF1 in mouse induced pluripotent stem cells. Nature 2010, 465:175-181.

118. Stadtfeld M, Apostolou E, Ferrari F, Choi J, Walsh RM, Chen T, Ooi SSK, Kim SY, Bestor TH, Shioda T, Park PJ, Hochedlinger K: Ascorbic acid prevents loss of Dlk1-Dio3 imprinting and facilitates generation of all-iPS cell mice from terminally differentiated B cells. Nat Genet 2012, 44:398-405.

doi:10.1186/gm354

Cite this article as: Fu X, Xu Y: Challenges to the clinical application of pluripotent stem cells: towards genomic and functional stability. Genome Medicine 2012, 4:55 